\title{
Short Communication: Genetic Evaluation of Milking Speed for Brown Swiss Dairy Cattle in the United States
}

\author{
G. R. Wiggans, ${ }^{\star 1}$ L. L. M. Thornton, ${ }^{*}$ R. R. Neitzel, $†$ and N. Gengler $¥ \S$ \\ *Animal Improvement Programs Laboratory, Agricultural Research Service, USDA, Beltsville, MD 20705-2350 \\ †Brown Swiss Association, Beloit, WI 53511-5456 \\ $\ddagger$ National Fund for Scientific Research, B-1000 Brussels, Belgium \\ §Animal Science Unit, Gembloux Agricultural University, B-5030 Gembloux, Belgium
}

\begin{abstract}
Genetic parameters and relative breeding values were estimated for milking speed of US Brown Swiss dairy cattle. Owner-recorded milking-speed scores on a scale of 1 (slow) to 8 (fast) were collected by the Brown Swiss Association as part of its linear type appraisal program starting in 2004. Data were 7,366 records for 6,666 cows in 393 herds. The pedigree file included information for 21,458 animals born in 1985 or later. Six unknown-parent groups that each included 4 birth years were defined. The model included fixed effects for herd appraisal date and parity-lactation stage and random effects for permanent environment, animal, and error. Within parity (1, 2, and $\geq 3), 6$ groups were defined: unknown calving date, four 90-d lactation stages, and lactations with $>400 \mathrm{~d}$ in milk. Heritability of 0.22 and repeatability of 0.42 were estimated by average-information REML; residual variance was 1.13. Little trend in estimated breeding value was found for cows born from 1999 through 2002. Although solutions increased with lactation stage for first-parity cows by 0.37 , no clear trend was found for later parities. Genetic evaluations for milking speed were expressed as relative breeding values with a mean of 100 and a standard deviation of 5 . The 121 bulls with $\geq 10$ daughters had milking speed evaluations that ranged from 83 to 112 and had correlations of 0.56 with productive life evaluations and -0.40 with somatic cell score evaluations. The association of faster milking speed with lower somatic cell score was not expected. The moderate heritability found for milking speed indicates that the evaluations (first released in May 2006) should be useful in detecting bulls with slow-milking daughters.
\end{abstract}

Key words: genetic evaluation, milking speed, Brown Swiss

Milking speed (MS) is an important trait to dairy producers. A cow that milks out slowly may disrupt the

Received May 25, 2006.

Accepted August 28, 2006.

${ }^{1}$ Corresponding author: wiggans@aipl.arsusda.gov flow of cows through the milking parlor, whereas cows that milk out quickly require less labor in the parlor, possibly leading to greater profit. However, fast-milking cows may be at increased risk for mastitis (Zwald et al., 2005), and intermediate MS may be optimal (Boettcher et al., 1998). One study found that faster MS was linked to high SCC but not to a higher incidence of mastitis (Rupp and Boichard, 1999).

A substantial portion of Brown Swiss semen is sold internationally. Information on daughter MS is usually available for Brown Swiss bulls from other countries, which makes MS information for US bulls desirable. The objective of this study was to estimate genetic parameters for MS of US Brown Swiss dairy cattle and to develop genetic evaluations for bulls.

Owner-recorded MS scores on a scale of 1 (slow) to 8 (fast) were collected by the Brown Swiss Association (Beloit, WI) as part of its linear type appraisal program starting in 2004. This scoring system is similar to many others worldwide. French Holsteins are scored for milking ease on a scale of 1 to 5 (Rupp and Boichard, 1999), and Canadian Holsteins also are scored on a scale of 1 to 5 for MS (Boettcher et al., 1998); Danish MS is scored from 1 to 9 (Sørensen et al., 2000). Scores are usually assigned by owners, and results are recorded through milk recording or by appraisers. Measurement of MS from electronic meters used during milk recording is being investigated. Several regions in Germany are collecting MS data with electronic meters (Rensing and Ruten, 2005).

Data were 7,366 records collected through March 2006 for 6,666 US Brown Swiss cows that calved at $\leq 68$ mo of age in 393 herds. The distribution of MS scores (Table 1) was skewed toward faster milking speeds. In total, 21,458 ancestors born during 1985 or later and 6 unknown-parent groups were included in the analysis. Each unknown-parent group included 4 birth years. Four 90-d lactation stages were defined within 3 parity groups ( 1,2 , and $\geq 3$ parities). Cows with unknown calving dates or $>400$ DIM (9.3\% of observations) were assigned to separate within-parity groups.

The variance component estimation program of Misztal et al. (2002) for average-information REML was 
Table 1. Frequency of milking speed scores

\begin{tabular}{lrr}
\hline & \multicolumn{2}{c}{ Records } \\
\cline { 2 - 3 } Score & $\mathrm{n}$ & \multicolumn{1}{c}{$\%$} \\
\hline 1 & 33 & 0.4 \\
2 & 151 & 2.0 \\
3 & 427 & 5.8 \\
4 & 869 & 11.8 \\
5 & 1,460 & 19.8 \\
6 & 1,581 & 21.5 \\
7 & 1,792 & 24.3 \\
8 & 1,053 & 14.3 \\
All & 7,366 & 100.0 \\
\hline
\end{tabular}

used. The animal model included fixed effects for herd appraisal date and parity-lactation stage and random effects for permanent environment, animal, and error. Inbreeding was ignored in the variance component estimation but was used in formation of the inverse of the relationship matrix for calculation of evaluations.

Estimated MS heritability was 0.22 and repeatability was 0.42 , which was somewhat different from previous studies. Heritability of MS was estimated to be 0.11 by Zwald et al. (2005) and 0.10 by Rensing and Ruten (2005) based on single animal observations; 0.15 by Boettcher et al. (1998); and 0.35, 0.27, and 0.17 for 3 Danish breeds by Sørensen et al. (2000). The variability in the heritability estimates might be less if the MS measure were more objective. Rensing and Ruten (2005) reported repeatability of measured MS within first lactation to be 0.47 . The residual variance obtained in our study was 1.13, which was comparable to other studies.

Figure 1 displays effect of lactation stage on MS within parity. For first-parity cows, solutions increased

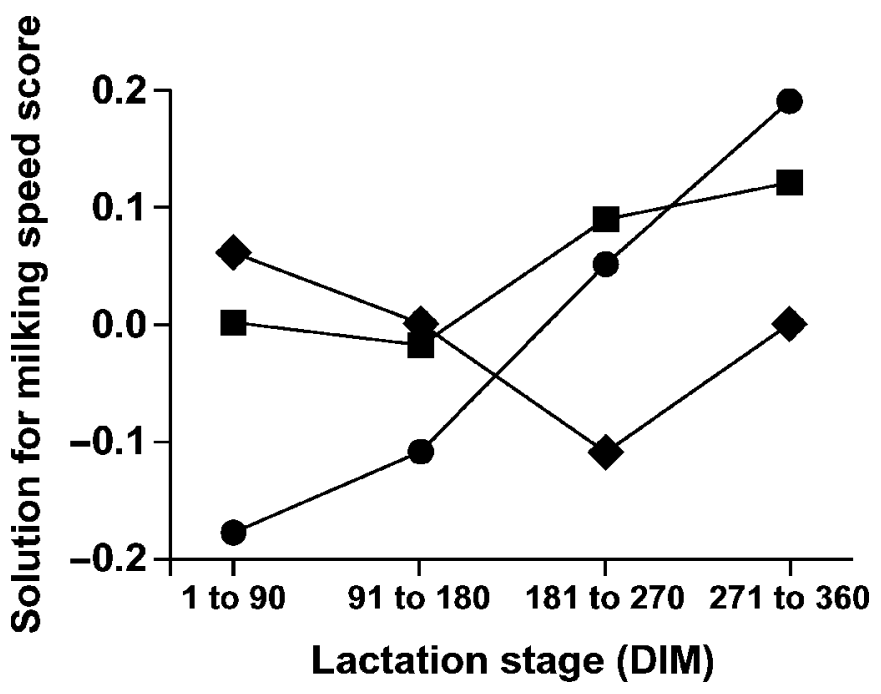

Figure 1. Effect of lactation stage on milking speed for parity 1 $(\bullet)$, parity $2(\mathbf{\square})$, and parities $\geq 3(\bullet)$. with lactation stage by 0.37 . No clear trend was observed for later parities. Little trend was found for EBV of cows born from 1999 through 2002.

Genetic evaluations for MS were expressed as relative breeding values with a mean of 100 and a standard deviation of 5 . The base group for the mean of 100 was bulls born from 1994 through 1999 with $\geq 10$ daughters. Genetic evaluations for those 121 bulls ranged from 83 to 112 .

Correlations between evaluations for MS and production traits for the base group of bulls were calculated. Significant $(P<0.0001)$ correlations were found between evaluations for MS and productive life (0.56) and SCS (-0.40). Correlation between MS and SCS evaluations was reduced to -0.14 and was not significant when calculated within sire of bull for the 60 bulls that had a sire with $\geq 5$ sons among the 121 bulls. Therefore, the large negative correlation for the base group may be the result of a few individuals. The association of faster MS with lower SCS was not expected based on the findings of Rupp and Boichard (1999), which were based on a subjective MS measure, and those of Zwald et al. (2005), which were based on electronically recorded milking durations for 29 large herds. Boettcher et al. (1998) reported genetic correlations of 0.41 and 0.25 between subjectively measured MS and lactation mean SCS for first and second parities, respectively. Although we did not evaluate mastitis incidence, the negative correlation between MS and SCS may indicate a lower incidence of mastitis with faster MS, perhaps because slow-milking cows do not get completely milked out, which leads to elevated SCS. Another possibility is that high SCS reflects an increased incidence of mastitis, which may have damaged udders and led to longer milking times. The subjective measurement of MS also may have contributed to this unexpected result. Another possible cause is breed differences, because Rupp and Boichard (1999) and Zwald et al. (2005) analyzed Holstein data. The negative correlation between MS and SCS found in this study was not consistent with other scientific results and was much reduced when calculated within sire of bull. Therefore, this correlation may not be observed in future samples. A few widely used sires in a breed with small population size can have a large influence on most traits in the whole population.

Correlations of MS and type evaluations are in Table 2 . The most negative correlations were -0.35 for teat length and -0.31 for strength. The highest positive correlations were 0.22 for dairy form and fore udder attachment. Rupp and Boichard (1999) and Zwald et al. (2005) also found a negative relationship between MS and teat length but little correlation between MS and fore udder attachment. 
Table 2. Correlation of milking speed evaluation with evaluations for type traits

\begin{tabular}{lrr}
\hline Trait & Correlation & $P$ \\
\hline Final score & 0.19 & 0.034 \\
Stature & -0.27 & 0.003 \\
Strength & -0.31 & 0.001 \\
Dairy form & 0.22 & 0.016 \\
Foot angle & -0.08 & 0.410 \\
Rear legs (side view) & -0.09 & 0.351 \\
Body depth & -0.06 & 0.498 \\
Rump angle & -0.07 & 0.459 \\
Rump width & -0.21 & 0.021 \\
Fore udder attachment & 0.22 & 0.016 \\
Rear udder height & 0.14 & 0.115 \\
Rear udder width & 0.19 & 0.041 \\
Udder depth score & 0.18 & 0.049 \\
Udder cleft & 0.18 & 0.053 \\
Front teat placement & 0.06 & 0.499 \\
Teat length & -0.35 & $<0.001$ \\
\hline
\end{tabular}

Genetic evaluations for MS can provide useful information for breeding decisions because of the moderate heritability of MS. The first USDA evaluations for Brown Swiss MS were released in May 2006. Because of international interest in MS (Interbull, 2006), MS evaluations may be extended to other breeds. The required data may be provided by AI organizations or from electronic meters through the DHI program. To include MS in an overall index, selection emphasis may need to be on an intermediate optimum. A too-rapid MS may be associated with an increase in milk leakage before milking.

\section{ACKNOWLEDGMENTS}

N. Gengler, research associate of the National Fund for Scientific Research (Brussels, Belgium), acknowledges the financial support of his organization.

\section{REFERENCES}

Boettcher, P. J., J. C. M. Dekkers, and B. W. Kolstad. 1998. Development of an udder health index for sire selection based on somatic cell score, udder conformation, and milking speed. J. Dairy Sci. 81:1157-1168.

Interbull (International Bull Evaluation Service). 2006. Description of National Genetic Evaluation Systems for dairy cattle traits as applied in different Interbull member countries. http://wwwinterbull.slu.se/national_ges_info2/begin-ges.html. Accessed July 30, 2006.

Misztal, I., S. Tsuruta, T. Strabel, B. Auvray, T. Druet, and D. H. Lee. 2002. BLUPF90 and related programs. Proc. 7th World Congr. Genet. Appl. Livest. Prod. 33:743-744.

Rensing, S., and W. Ruten. 2005. Genetic evaluation for milking speed in German Holstein population using different traits in a multiple trait repeatability model. Interbull Bull. 33:163-166.

Rupp, R., and D. Boichard. 1999. Genetic parameters for clinical mastitis, somatic cell score, production, udder type traits, and milking ease in first lactation Holsteins. J. Dairy Sci. 82:21982204.

Sørensen, M. K., J. Jensen, and L. G. Christensen. 2000. Udder conformation and mastitis resistance in Danish first-lactation cows: Heritabilities, genetic and environmental correlations. Acta Agric. Scand., A Anim. Sci. 50:72-82.

Zwald, N. R., K. A. Weigel, Y. M. Chang, R. D. Welper, and J. S. Clay. 2005. Genetic evaluation of dairy sires for milking duration using electronically recorded milking times of their daughters. J. Dairy Sci. 88:1192-1198. 